\title{
Exploration of the Innovative Development of Secondary Vocational Education in the New Period
}

\author{
Ruyi Cai \\ Electronic Engineering Institute \\ Tianjin University of Technology and Education \\ Tianjin, China
}

\author{
Shixin $\mathrm{Li}^{*}$ \\ Electronic Engineering Institute \\ Tianjin University of Technology and Education \\ Tianjin, China \\ *Corresponding author
}

\author{
Chaonan Fan \\ Electronic Engineering Institute \\ Tianjin University of Technology and Education \\ Tianjin, China
}

\begin{abstract}
In the new period, the demand for technologybased talents in the society is increasing. Secondary vocational schools as educational academies for training technical talents should also explore innovative development ideas in light of changes in social needs in order to improve the quality of secondary vocational education and meet students' learning needs and development needs. Therefore, the article proposes corresponding innovative development ideas for the innovative development of secondary vocational education, the ideas like that innovative development of secondary vocational education concept; innovative development of secondary vocational teaching mode; highlight the school-running characteristics of secondary vocational schools; pay attention to the cultivation of students' innovation and entrepreneurial ability; optimization of the quality of secondary vocational teachers. By implementing these measures, we can improve the quality of secondary vocational education and meet the learning needs and selfdevelopment of students.
\end{abstract}

Keywords-New period; Secondary vocational education; Innovation and development; Innovative ideas

\section{ANALYSIS ON THE NECESSITY OF INNOVATIVE}

DEVELOPMENT OF SECONDARY VOCATIONAL EDUCATION IN THE NEW PERIOD

In the new era, the idea of innovative development of secondary vocational education is to break through conventional thinking and overcome the limitations of the status quo on the basis of the laws and trends in the development of secondary vocational education, and to guide the development of secondary vocational education with new methods and concepts.[1]

The necessity of innovative development in secondary vocational education is mainly reflected in the following two aspects. First, regarding secondary vocational schools themselves. With the advancement of society, the demand for secondary vocational education in China is constantly increasing, and the number of secondary vocational schools is increasing. Only by carrying out effective education reform and innovation can we improve the quality of secondary vocational schools, and attract more qualified students to achieve the common development of secondary vocational schools and students. The second is about the entire education industry. Only through effective education and innovation development can vocational schools promote the progress and optimization of the entire education industry, thus improving the overall school education level in China. Therefore, in the actual development of secondary vocational schools, effective development strategies must be adopted to improve the quality of secondary vocational education and further improve the competitiveness of secondary vocational schools.

\section{NEW IDEAS FOR THE DEVELOPMENT OF SECONDARY VOCATIONAL EDUCATION IN THE NEW PERIOD}

\section{A. The Innovative Development of Secondary Vocational Education Concept}

In the process of continuous development, secondary vocational schools should first carry out innovative development of educational concepts. What is education Concept? The concept of education actually refers to educational thinking, which has the role of leading educational methods. With the development of the education industry, the concept of education in secondary vocational schools should not stagnate and needs further improvement and innovation. For example, the founding centered on quality education, Vocational Education-oriented Secondary Vocational Education Concept, Strengthen quality education and professional education for students, Highlight the professionalism and technicality of secondary vocational education, In order to promote the optimal development of secondary vocational education.[2] In addition, secondary vocational schools should also actively study the outstanding educational concepts of other schools and apply and innovate in combination with the actual conditions of their own schools. 


\section{B. Innovative development of teaching mode in secondary vocational schools}

In the new period, the teaching mode of secondary vocational education must have new breakthroughs and new developments. First, from the previous care-type teaching to interactive teaching. In the teaching classroom, teachers and students strengthen interaction, exchange and cooperation with each other, and successfully achieve teaching and learning goals in a relaxed and enjoyable teaching scenario. In the teaching process of each professional of secondary vocational education, teachers and students play different roles. Students will use external learning conditions and their own continuous efforts to cultivate their own good spirit of independent entrepreneurship, courage to innovate, and collaboration. It will lay a solid foundation for future achievements and individual values in all jobs. Second, from closed education to open teaching. That is to say, it is the use of computers and the Internet and other high-tech advanced equipment and means to carry out effective teaching methods for curriculum teaching. In the process of implementing open teaching, teachers can use assistive teaching tools such as computers and projectors to visualize the various kinds of knowledge that they need to teach students, and make it easier for students to understand and master these knowledge points.[3] Instructors in teaching should be good at breaking through the constraints of various teaching materials, and timely replenish all kinds of new technologies and new results that are closely related to the profession to all professional courses and improve the efficiency of professional classroom teaching.

\section{Highlighting the school-running characteristics of secondary vocational schools}

In order to achieve long-term development, secondary vocational schools must highlight the characteristics and philosophy of secondary vocational schools. At present, many secondary vocational schools do not realize this, thus being at a disadvantage in social competition, with poor quality of students, low employment rate of students and poor development prospect. Therefore, only by carrying out innovative development of school-running characteristics can we improve the educational quality of secondary vocational schools. Specific efforts should be made in the following aspects.

(1) Building educational brand. Secondary vocational schools should build the specialties with the strongest teachers, the most advanced equipment and the best professional prospect as brand specialties, and set them as the signboards of secondary vocational schools, so as to attract more high-quality students. (2) Implementing school-enterprise cooperation and expanding resettlement channels. Secondary vocational schools should adhere to the principle of employment-oriented and service-oriented, and implement school-enterprise cooperation to actively broaden the employment channels and carry out the form of order enrollment, so as to form the employment characteristics of more famous enterprises and more students' self - employment.

\section{Attach importance to the cultivation of students' innovative and entrepreneurial abilities}

Secondary vocational schools must attach importance to the cultivation of students' innovation and entrepreneurship. We should integrate the curriculum system of innovation and entrepreneurship education into the personnel training scheme, clarify the related requirements of innovation and entrepreneurship literacy, and enrich and improve related courses. We should also strengthen the integration of innovation and entrepreneurship literacy with other disciplines and practical training courses, so that innovation and entrepreneurship literacy become an important part of the talent training scheme. Vigorously carry out a series of activities focusing on innovation and entrepreneurship.[5] Such as organizing students to display their skills, participating in provincial and municipal skill competitions, and encouraging them to participate in series of activities on topics such as student start-up companies. Improve students' innovation and entrepreneurship ability, and enhance students' adaptability.[4]

\section{E. Optimizing and improving the quality of teachers in secondary vocational schools}

The most important point in the innovative development of secondary vocational education is to improve the quality of secondary vocational school education. And it depends on improving the optimization and improvement of secondary vocational school teachers. Therefore, in the process of innovative development, secondary vocational schools need to build a high-quality teaching staff to better carry out teaching services for students. Optimizing secondary vocational teachers must do the following: (1) Adhere to the introduction of outstanding teachers. Secondary vocational schools must recruit highly educated, highly capable teachers with extensive teaching experience and scientific research experience. At the same time, they should provide teachers with good development prospects and promote the common development of secondary vocational schools and teachers. (2)Adhere to outstanding teachers go out. Secondary vocational schools should regularly organize their teachers to study and exchange with other schools. At the same time, they should also send outstanding teachers to study abroad to study the outstanding schooling concepts of vocational education in Western countries. (3)Implement effective flow of outstanding teachers. Secondary vocational schools can exchange excellent teachers with other schools to learn and introduce the advantages of his school to the school so as to improve the quality of secondary school education. In short, only when a secondary vocational school has a group of high-quality and high-ability teachers can improve the quality of education and research of secondary vocational schools, so as to improve the social competitiveness of secondary vocational schools and achieve the sustainable development of secondary vocational schools.

\section{CONCLUSION}

In the new period, the innovative development ideas of secondary vocational education must conform to the trend of the times and always run through the professional education and teaching process of secondary vocational schools. Only in this way can we build a harmonious and pleasant teaching 
environment, inspire students' interest in learning, encourage teachers to actively overcome teaching difficulties and priorities, and cultivate a batch of high-quality secondary vocational talents.[6] In the current domestic and foreign vocational education research, the innovation of secondary vocational education and teaching has always been the focus of many scholars. Compared with other countries, the number of secondary vocational education groups in our country is relatively high, so the teaching innovation of secondary vocational education must be persistent, choose the appropriate innovative ideas and paths with the times, and deliver a solid and high-quality Chinese vocational talent for the realization of the great "Chinese Dream".

\section{REFERENCES}

[1] Rolf Becker, David Glauser. Vocational Education and Training, Vocational Baccalaureate or Academic High School? An Empirical Analysis of Social Selective Transitions to Upper Secondary Education in the German-Speaking Part of Switzerland[J]. Swiss Journal of Sociology, 2018, 44(1)

[2] Jiehan Zhou, Jukka Riekki, Mätti Hämäläinen, Pasi Mattila, Xinguo Yu, Xiwei Liu, Weishan Zhang. China-Fin land EduCloud Platform Towards Innovative Education[M].Springer International Publishing: 2018-06-12.

[3] Gun-Britt Wärvik, Viveca Lindberg. Integration between School and Work: Changes and Challenges in the Swedish VET 19702011[M].Springer Singapore: 2018-06-21.

[4] Philipp Grollmann. Varieties of "Duality": Work-Based Learning and Vocational Education in International Comparative Research [M]. Springer Singapore: 2018-06-21.

[5] Svein Michelsen, Marja-Leena Stenström. Vocational Education in the Nordic Countries[M].Taylor and Francis:2018-05-21.

[6] Elly Singer, Sandie Wong. Reflections of pioneers in early childhood education research on their collaboration with practitioners in the development of theories and innovative practices[J]. Early Years, 2018, 38(2). 